\title{
PROSEDUR PENANGANAN DOKUMEN KAPAL MUATAN CURAH KERING DI DERMAGA TUKS INALUM PADA PT.GESURI LIOYD CABANG KUALA TANJUNG
}

\author{
${ }^{1}$ Lilis , ${ }^{2}$ Eka Fransiska , ${ }^{3}$ Cindy Ivana Uliarti Situmeang \\ ${ }^{1}$ NAUTIKA, ${ }^{2}$ Teknika ${ }^{3}$ KPNK, Politeknik Adiguna Maritim Medan \\ email: lilismpd1976@gmail.com
}

\begin{abstract}
Abstrak. Tugas dari perusahaan pelayaran, PT. Gesuri Lloyd Cabang Kuala Tanjung yaitu menangani dokumen dari kapal yang akan tiba dan berangkat sampai kapal selesai melakukan aktifitas bongkar/muat barang didermaga pelabuhan Terminal Untuk Kepentingan Sendiri (TUKS) INALUM. Sebagai agen pelayaran wajib mengetahui prosedur penanganan dokumen kapal tiba dan berangkat, karena kegiatan tersebut adalah kegiatan inti dari operasional perusahaan pelayaran yang bergerak di bidang keagenan. Dermaga TUKS INALUM merupakan singkatan dari Terminal Untuk Kepentingan Sendiri yang berarti tidak untuk kepentingan umum dikarenakan salah satu perusahaan besar memiliki dermaganya sendiri yaitu PT. INALUM (Indonesia Asahan Aluminium). PT. Gesuri Lloyd Cabang Kuala Tanjung bekerja sama dengan perusahaan bongkar muat yaitu PT. Kuala Jaya Samudera dan PT. Duet Pratama Samudera. Tujuan penelitian ini adalah untuk mengetahui dan menjelaskan prosedur penanganan dokumen kedatangan dan keberangkatan kapal di pelabuhan TUKS INALUM dan untuk mengetahui instansi-instansi terkait dalam prosedur penanganan dokumen kapal dipelabuhan TUKS INALUM. Instansi-instansi yang terkait di Kuala Tanjung menjalin kerja sama yang baik kepada perusahaan PT. Gesuri Lloyd Kuala Tanjung, tetapi terkadang terdapat kendala dalam menangani dokumen baik itu disebabkan oleh alat untuk bongkar maupun petugas yang terlibat didalam nya sehingga mengkibatkan keterlambatan dalam menangani dokumen. Metode yang dilakukan untuk pengumpulan data adalah metode observasi atau pengamatan, interview atau wawancara, studi pustaka dan dokumentasi.
\end{abstract}

Kata Kunci: Dokumen,Kapal,Curah Kering,PT.Gesuri lioyd Cabang Kuala Tanjung

\begin{abstract}
The duties of the shipping company, PT. Gesuri Lloyd Kuala Tanjung Branch, which handles documents from ships that will arrive and depart until the ship has finished loading/unloading goods at the INALUM Terminal for Own Interest (TUKS) port. As a shipping agent, you must know the procedures for handling documents for ships arriving and departing, because these activities are the core activities of the operations of shipping companies engaged in the agency sector. TUKS INALUM Pier is an abbreviation of Terminal for Self Interest which means not for public interest because one of the big companies has its own dock, namely PT. INALUM (Indonesia Asahan Aluminum). PT. Gesuri Lloyd Kuala Tanjung Branch in collaboration with a loading and unloading company, namely PT. Kuala Jaya Samudera and PT. Ocean Primary Duet. The purpose of this study was to find out and explain the procedures for handling ship arrival and departure documents at the TUKS INALUM port and to find out the relevant agencies in the procedures for handling ship documents at the TUKS INALUM port. Relevant agencies in Kuala Tanjung establish good cooperation with the company PT. Gesuri Lloyd Kuala Tanjung,
\end{abstract}


but sometimes there are obstacles in handling documents, both caused by the tools for unloading and the officers involved in it, resulting in delays in handling documents. The method used for data collection is the method of observation or observation, interviews or interviews, literature studies and documentation

Keywords: : Documents, Ships, Dry Bulk, PT. Gesuri lioyd Kuala Tanjung Branch

\section{PENDAHULUAN}

Dokumen kapal adalah dokumen yang merupakan surat-surat penting harus dimiliki oleh setiap pemilik/perusahaan atau individu yang ingin mengoperasikan kapalnya. Dalam hal ini setiap kapal yang akan berlayar dilaut lepas harus dilengkapi dokumen pendukungnya. Tanpa ada dokumen yang sah maka pejabat berwenang berhak tidak memberi izin berlayar terhadap kapal tersebut. Peranan perusahaan pelayaran sangat penting untuk mengurusi dokumen kapal.

PT. Gesuri Lloyd Cabang Kuala Tanjung adalah perusahaan pelayaran yang menyediakan jasa Keagenan sebagai cabang agen / sub agen yang bertugas untuk menangani dokumen kedatangan dan keberangkatan kapal yang akan masuk dan keluar dari pelabuhan. Suatu perusahaan pelayaran mengoperasikan kapal-kapalnya dari pelabuhan satu kepelabuhan lainnya. Sehingga perusahaan pelayaran harus menangani kapal yang dioperasikan pada saat dipelabuhan yang disinggahinya. Kegiatan pengurusan dokumen untuk kedatangan dan keberangkatan kapal yang akan masuk dan keluar pelabuhan pada pihak atau instansi yang terkait.

Dalam proses menangani dokumen kapal, agen selalu menghubungi beberapa pihak terkait diantaranya Kantor Syahbandar dan Otoritas Pelabuhan ( KSOP ) dalam penanganan dokumen kapal dan juga sertifikatnya, PT. PELINDO I dalam penanganan pandu dan tunda, Imigrasi dalam penanganan passport dan izin tinggal crew, Bea dan Cukai dalam penanganan muatan yang disesuaikan dengan BC 1.0 dan BC 1.1, kemudian menghubungi Karantina Kesehatan Pelabuhan untuk memeriksa kapal serta crew kapal apakah dalam keadaan sehat dan tidak membawa penyakit selama dalam pelayaran.

\section{METODE PENELITIAN}

Dalam melaksanakan tulis ini, penulis menggunakan beberapa metode atau cara kerja pengumpulan data. Metode yang digunakan dalam melaksanakan penulisan ini adalah :

\section{Metode Observasi Lapangan (Field Study)}

metode ini dilakukan dengan cara wawancara langsung kepada pihak-pihak yang terkait yang berhubungan dengan masalah yang diteliti, diantaranya terhadap karyawan PT. Gesuri Lloyd Cabang Kuala Tanjung. Selain wawancara juga dilakukan pengamatan secara langsung terhadap objek. Penulis mempelajari dan mencari penyesuaian antara keterangan yang diperoleh dengan keadaan lapangan sebenarnya.

\section{Metode Studi Perpustakaan (Library Study)}

Yaitu suatu metode yang diperoleh dengan membaca buku-buku yang berkaitan dengan persoalan yang akan dibahas dalam suatu penulisan dan merupakan bahan tambahan yang menyediakan informasi untuk melengkapi suatu penulisan.

\section{HASIL DAN PEMBAHASAN}

\section{A.Sejarah Singkat Perusahaan}

Perusahan pelayaran PT. Gesuri Lloyd Cabang Kuala Tanjung resmi di dirikan pada tahun 1964 di Jl. Pelabuhan PT. Inalum Desa Kuala Tanjung Kec. Sei Suka, Kab. Batu Bara. Perusaahan pelayaran PT. Gesuri Lloyd Cabang Kuala Tanjung bekerjasama dengan Perusahaan Bongkar Muat (PBM) PT. Duet Pratama Samudera dan PT. Kuala Jaya Samudera untuk proses bongkar dan muat dari kapal ke lapangan penumpukan dan dari gudang ke atas kapal. Pusat dari PT. Gesuri Lloyd terletak di Jl. Tiang Bendera IV No. 45 Jakarta Barat-11230.

Memperhatikan bahwa aktivitas pada perusahaan tempat penulis praktek terdiri dari beberapa aktivitas yaitu :

a. PT. Gesuri Lloyd Cabang Kuala Tanjung sebagai perusahaan pelayaran yang bergerak di bidang keagenan saja, perusahaan ini di tunjuk oleh Owner's atau pemilk kapal untuk mengageni kapal lokal maupun kapal asing. Kapal yang di ageni oleh PT.Gesuri Lloyd Cabang Kuala Tanjung adalah kapal cargo, kapal tanker dan tug boat/ tongkang. 
b. PT. Gesuri Lloyd Cabang Kuala Tanjung sebagai perusahaan pelayaran yang melayani seluruh kebutuhan kapal seperti Bunker (penyediaan minyak) Fresh water, Membawa Crew kapal, Supply bahan makanan berobat jika ada yang sakit dan kebutuhankebutuhan lainya.

\section{B. Prosedur Penanganan Dokumen Kapal di Dermaga TUKS INALUM.}

\section{Penanganan Dokumen Sebelum Kapal Tiba Di Dermaga.}

Jauh sebelum kapal tiba pihak pemilik kapal sudah memberikan informasi melalui via telepon dan email, mengenai rencana kedatangan kapal dan mengirimkan lampiran untuk pengajuan permohonan Pemberitahuan Kedatangan Kapal (PKK) pada pihak terkait sebagai berikut :

a. Rencana Pola Trayek (RPT)

Adalah surat persetujuan penempatan kapal berbendera Indonesia yang melayani trayek tetap dan teratur dalam rangka menunjang angkutan laut dalam negeri.

b. Letter of Appointment

Adalah surat penunjukan keagenan kapal. c.Sertifikat Surat Laut / Surat Tanda Kebangsaan

Adalah surat yang berisikan pernyataan kebangsaan kapal, maka atas dasar surat ini pihak kapal berhak mengibarkan bendera kebangsaan dari Negara yang memberikan sertifikat dan berhak mendapatkan perlindungan hukum.

d. Surat Ukur Internasional / International Tonnage Certificate

Adalah sertifikat yang menerangkan bahwa suatu dokumen kapal yang menguraikan lebih jelas tentang, ukuran-ukuran pokok seperti panjang dan lebar kapal, serta tonase kotor dan tonase bersih kapal.

e. Ship Particular

Adalah surat yang berisi tentang data kapal.

\section{f. Cargo Manifest}

Adalah surat yang berisi daftar semua perincian barang muatan yang ada dikapal tersebut.

g. Bill of Lading

Adalah surat bukti barang muatan yang berfungsi sebagai, tanda terima sah barang muatan, perjanjian pengangkutan, dan sebagai bukti kepemilikan barang. h. Crew List

Adalah daftar awak kapal

Setelah pihak agen mendapatkan kepastian kedatangan , maka agen pelayaran harus memberitahukan kedatangan kapal kepada instansi yang berwenang seperti :

a. Membuat dan menyerahkan surat Pemberitahuan Kedatangan Kapal kepada Kantor Syahbandar dan Otoritas Pelabuhan (KSOP) dengan melampirkan dokumen sebagai berikut:

1) Surat Pemberitahuan Kedatangan Kapal ( PKK )

2) Rencana Pola Trayek ( RPT )

3) Surat Penunjukan Keagenan / Letter of Appoinment (LOA)

4) Surat Laut

5) Surat Ukur / International Tonnage Certificate (ITC)

6) Ship Particular

7) Cargo Manifest

8) Bill of Lading

9) Crew List

b. Membuat surat Rencana Kedatangan Sarana Pengangkut (RKSP) dan menyerahkannya ke Kantor Pelayanan dan Pengawasan Bea dan Cukai (KPPBC) dengan melampirkan dokumen sebagai berikut:

1) Surat Persetujuan Berlayar (Last Port Clearance)

2) Crew list

3) Manifest

4) Ship Particular

5) Surat Laut

6) Surat Ukur

c. Membuat dan menyerahkan surat pemberitahuan kapal tiba, surat permohonan izin sandar, dan surat permohonan izin masuk ke dermaga TUKS INALUM.

d. Memberitahukan kedatangan kapal secara online kepada kantor Kesehatan Pelabuhan.

e. Memberitahukan kedatangan kapal secara online kepada PT. PELINDO I Cabang Kuala Tanjung dengan melampirkan dokumen kapal seperti ship particular, surat ukur, dan surat laut untuk didaftarkan di PELINDO, setelah terdaftar maka PELINDO akan memberikan dokumen Pemberitahuan Kunjungan Kapal (PKK) gunanya agar bisa membuat Permintaan Pelayanan Kapal dan Barang (PPKB) yaitu pandu dan tunda.

f. Satu hari sebelum kapal akan tiba agen membuat surat permohonan izin olah gerak sandar kapal dan menyerahkannya ke Kantor Syahbandar dan Otoritas Pelabuhan (KSOP) dengan melampirkan dokumen :

1) Surat Pemberitahuan Kedatangan Kapal ( PKK )

2) Rencana Pola Trayek ( RPT )

3) Surat Penunjukan Keagenan / Letter of Appoinment (LOA)

4) Surat Laut 
5) Surat Ukur / International Tonnage Certificate (ITC)

6) Ship Particular
7) Cargo Manifest
8) Bill of Lading
9) Crew List

g.Agen mempersiapkan dokumen yang dibawa ke atas kapal pada saat kapal telah sandar seperti :

1) Arrival Condition

Merupakan dokumen yang menyatakan kondisi kapal saat tiba seperti jumlah bahan bakar, air tawar dan draft tiba.

2) Tug Boat Usage Berthing

Merupakan tug boat yang akan digunakan saat proses penyandaran kapal

3) Warta Kapal

Merupakan suatu bentuk laporan mengenai kondisi umum kapal dan muatan sebelum kapal memasuki pelabuhan maupun sebelum meninggalkan pelabuhan yang ditanda tangani oleh kapten.

4) Memorandum

Adalah dokumen yang berisi tentang daftar sertifikat asli kapal

5) Notice of Readiness ( NOR )

Adalah surat keterangan kesiapan kapal untuk melakukan aktifitas yang ditandatangani oleh nahkoda.

6) Inward Manifest

Merupakan manifest yang diterbitkan oleh agen untuk dilampirkan pada tanda terima manifest untuk kantor Bea Cukai yang ditanda tangani oleh kapten.

\section{Penanganan Dokumen Saat Kapal Tiba}

Adapun penanganan dokumen saat kapal tiba adalah :

a). Berhubung Negara Indonesia sedang dilanda wabah COVID-19, pihak agen menghubungi pihak kantor kesehatan pelabuhan untuk terlebih dahulu melakukan pemeriksaan kesehatan crew dan kapal diarea labuh jangkar apabila kapal yang akan datang pelabuhan terakhirnya dari luar Negara Indonesia dan apabila kapal tersebut pelabuhan terakhir yang disinggahinya merupakan pelabuhan Indonesia maka pemeriksaan dilaksanakan saat kapal telah sandar.

b). Setelah crew dan kapal dinyatakan dalam kondisi tidak terjangkit wabah virus, pihak karantina mengizinkan kapal sandar didermaga.

c). Agen menghubungi petugas pandu untuk melakukan proses penyandaran. d) Saat kapal telah sandar, petugas imigrasi memeriksa dokumen crew seperti buku pelaut dan passport pada kapal yang datang dari luar negeri

e). Agen mengambil dokumen asli kapal beserta buku pelaut crew kapal untuk diserahkan dan diperiksa petugas syahbandar dan menyerahkan dokumen yang harus ditandatangani oleh kapten seperti tug boat usage, arrival condition, inward manifest, Notice of Readiness (NOR), dan memorandum.

f). Selanjutnya agen menyerahkan Notice of Readiness ( NOR ) yang telah ditanda tangani kapten terlebih dahulu kepada penerima barang (consignee) yaitu PT. INALUM untuk ditanda tangani.

g). Agen menyerahkan inward manifest kepada Kantor Bea dan Cukai.

h). Selanjutnya agen melaksanakan clearance in ke Kantor Kesehatan Pelabuhan dengan membawa dokumen seperti buku kesehatan kapal ( green book ), surat izin berlayar karantina kesehatan, sertifikat kesehatan crew, sertifikat sanitasi kapal, sertifikat obat kapal, sertifikat kualitas air tawar, surat persetujuan berlayar, crew list, dan manifest.

i). Setelah agen telah mengisi memorandum kapal, selanjutnya agen menyerahkan dokumen yang dibutuhkan untuk pemeriksan di Kantor KSOP seperti, arrival condition, surat persetujuan berlayar, warta kapal, buku pelaut dan sertifikat asli dokumen kapal.

j). Kemudian agen membuat daily report atau laporan harian mengenai aktifitas kapal sejak kapal tiba hingga akan berlayar kepelabuhan selanjutnya dan time sheet yang merupakan dokumen yang digunakan untuk mencatat waktu kerja actual terhadap perintah atau proyek yang juga dapat menentukan operasi, lokasi, dan kategori atau jenis tugas yang dilakukan.

\section{Penanganan Dokumen Keberangkatan Kapal}

Setelah agen telah mendapatkan tanggal dan jam estimasi selesai bongkar dari pihak perusahaan bongkar muat, agen selanjutnya mengurus dokumen keperluan untuk keberangkatan kapal pada instansi seperti berikut :

a). Agen membuat Laporan Keberangkatan Kapal (LKK), Laporan Kedatangan dan Keberangkatan Kapal (LK3), surat permohonan persetujuan olah gerak kapal berlayar dan surat permohonan persetujuan berlayar dan diserahkan ke Kantor Syahbandar dan Otoritas Pelabuhan (KSOP).

b). Kemudian agen mempersiapkan dokumen untuk dibawa ke atas kapal yang akan ditandatangani kapten seperti : 
1) Departure Condition

Merupakan dokumen yang menyatakan kondisi kapal saat akan berlayar seperti jumlah bahan bakar, air tawar dan draft keberangkatan.

2) Notice of Readiness

Yang telah ditanda tangani oleh pihak penerima barang.

3) Tug Boat Usage Unberthing

Merupakan tug boat yang akan digunakan saat proses keberangkatan kapal.

4). Outward Manifest

Merupakan manifest keberangkatan yang ditanda tangani oleh kapten untuk lampiran tanda terima outward manifest kepada kantor Bea dan Cukai.

c). Selanjutnya agen memberitahu keberangkatan kapal ke Kantor Kesehatan Pelabuhan dengan membawa lampiran surat persetujuan berlayar dari Kantor Syahbandar dan membayarkan administrasi seperti Port Health Quarantine Clearance.

d). Setelah agen menyelesaikan dokumen keberangkatan pada instansi yang terkait, agen naik ke atas kapal dan menyerahkan kembali dokumendokumen kapal yang diambil pada saat kapal tiba.

\section{Peran Instansi Yang Terkait Dalam Penanganan Dokumen Kedatangan dan Keberangkatan Kapal \\ a). KANTOR SYAHBANDAR dan OTORITAS PELABUHAN}

Pada saat pengurusan dokumen kedatangan kapal agen menyerahkan dokumen yang telah di isi dikantor untuk diproses di kantor Syahbandar adapun dokumen dokumen tersebut adalah Memorandum yang telah ditanda tangani oleh kapten kapal. Arrival Condition, Surat Persetujuan Berlayar dari pelabuhan sebelumnya, warta kapal yang telah di tanda tangani oleh kapten kapal dan sertifikat kapal yang asli seperti:

\section{1). Surat Laut (Nationality Certificate)}

Surat laut / Nationality Certificate yaitu sertifikat yang menyatakan tanda kebangsaan kapal yang diberikan oleh Pemerintah Negara. Kapal tersebut berhak atas perlindungan hukum dari Negara tersebut dan kapal berhak mengibarkan bendera dari Negara dimana kapal itu didaftarkan.

2). Surat Ukur Internasional (International Tonnage Certificate)

Surat Ukur Internasional / International Tonnage Certificate yaitu menyatakan tincian mengenai ukuran/ tonnage kapal, yang terdiri dari volume keseluruhan, panjang kapal, lebar kapal, isi kotor (gross tonnage), da nisi bersih (net tonnage)

3).Sertifikat Klasifikasi Mesin (Certificate of Classification of Machine). Sertifikat Klasifikasi Mesin / Certificate of Classification of Machine yaitu sertifikat yang berisikan tentang rincian mesin yang digunakan oleh kapal.

4). Sertifikat Klasifikasi Lambung (Certificate of Hull)

Sertifikat Klasifikasi Lambung / Certificate of Hull yaitu sertifikat yang berisikan tentang klasifikasi lambung kapal.

5). Sertifikat Keamanan Internasional (Internasional Ship Security Certificate)

Sertifikat Keamanan Internasional / Internasional Ship Security Certificate yaitu sertifikat yang menyatakan bahwa kapal dilengkapi sistem keamanan dan peralatan keamanan.

6). Izin Stasiun Radio (Licencia Regkament Station The Radio)

Izin Stasiun Radio / Licencia Regkament Station The Radio yaitu sertifikat yang menyatakan perizinan yang dikeluarkan oleh Direktorat Sumber Daya dan Perangkat Pos dan Inforatika sebagai salah satu jenis izin penggunaan spectrum frekuensi radio.

7). Sertifikat Garis Muat Internasional (International Load Line Certificate)

Sertifikat Garis Muat Internasional / International Load Line Certificate yaitu sertifikat yang menetapkan lambung kapal yang boleh timbul diatas permukaan air laut minimum dan maksimum sertifikat ini berisikan tentang garis muat internasional.

8). Sertifikat Keselamatan Perlengkapan Kapal Barang (Cargo Ship Safety Equipment Certificate)

Sertifikat Keselamatan Perlengkapan Kapal Barang / Cargo Ship Safety Equipment Certificate yaitu sertifikat yang meyatakan perlengkapanperlengkapan diatas kapal, diterbitkan setelah pemeriksaan alat-alat penolong, keselamatan, dan perlengkapan lainnya.

9). Sertifikat Keselamatan Konstruksi Kapal Barang (Cargo Ship Safety Construction Certificate)

Sertifikat Keselamatan Konstruksi Kapal Barang / Cargo Ship Safety Construction Certificate yaitu sertifikat yang menyatakan konstruksi-konstruksi kapal, yang terdiri dari badan kapal, mesin, perlengkapan dan lain-lain mengenai keamanan yang telah layak laut.

10). Sertifikat Keselamatan Radio Kapal Barang (Cargo Ship Safety Certificate)

Sertifikat Keselamatan Radio Kapal Barang / Cargo Ship Safety Certificate yaitu sertifikat yang 
menerangkan bahwa kapal dilengkapi dengan perangkat penerima dan pemancar radio yang memenuhi syarat-syarat sesuai dengan class kapal yang bersangkutan.

11) Sertifikat Bebas Tindakan Sanitasi (Ship Sanitation Control Exemtion Certificate)

Sertifikat Bebas Tindakan Sanitasi / Ship Sanitation Control Exemtion Certificate yaitu sertifikat yang menyatakn kapal bebas dari hama tikus. Sertifikat ini ditanda tangani oleh kantor kesehatan pelabuhan.

12). Sertifikat Manajemen Keselamatan Internasional (Safety Management Certificate)

Sertifikat Manajemen Keselamatan Internasional / Safety Management Certificate yaitu sertifikat yang diterbitkan untuk membuktikan bahwa perusahaan dan manajemen di atas kapal bekerja/terselenggara sesuai dengan system keselamatan yang telah disahkan.

13). Dokumen Keselamatan Pengawakan Minimum (Minimum Safe Manning)

Dokumen Keselamatan Pengawakan Minimum / Minimum Safe Manning yaitu sertifikat yang menerangkan jumlah perwira dan anak buah kapal lainnya beserta jabatan yang telah ditentukan.

14). Dokumen Penyesuaian Manajemen Keselamatan Sementara (Document of Complience)

Dokumen Penyesuaian Manajemen Keselamatan Sementara / Document of Complience yaitu dokumen yang diterbitkan oleh pemerintah untuk suatu perusahaan yang telah memenuhi persyaratan ISM Code.

15). Sertifikat Nasional Pencegahan Pencemaran Minyak Dari Kapal (National Oil Polution Prevention Certificate)

Sertifikat Nasional Pencegahan Pencemaran Minyak Dari Kapal / National Oil Polution Prevention Certificate yaitu sertifikat yang menyatakan bahwa kapal tersebut memiliki peralatan mencegah terjadinya pencemaran polusi dari minyak selama kapal dalam pengoperasian.

16). Sertifikat Internasional Ganti Rugi Pencemaran Oleh Minyak (National Oil Polution Damage Certificate)

Sertifikat Internasional Ganti Rugi Pencemaran Oleh Minyak / National Oil Polution Damage Certificate merupakan sertifikat diwajibkan pemerintah pada pemilik kapal untuk mendapatkan jaminan dari asuransi atau lembaga penjamin lainnya sebagai penanggung resiko apabila terjadi kecelakaan pada kapal yang memiliki bunker yang berisi bahan bakar.
17). Sertifikat Pencegahan Kotoran (National Sewage Polution Prevention)

Sertifikat Pencegahan Kotoran / National Sewage Polution Prevention yaitu sertifikat yang menyatakan bahwa kapal tersebut memiliki peralatan mencegah terjadinya pencemaran polusi dari kotoran selama kappa dalam pengoperasian.

18) Sertifikat Pencegahan Pencemaran Udara (National Air Polution Prevention Certificate)

Sertifikat Pencegahan Pencemaran Udara / National Air Polution Prevention Certificate yaitu sertifikat yang menyatakan bahwa kapal tersebut memiliki peralatan mencegah terjadinya pencemaran polusi dari udara selama kapal dalam pengoperasian.

19) Rencana Pengoperasian Trayek (RPT)

Adalah surat persetujuan penempatan kapal berbendera Indonesia yang melayani trayek tetap dan teratur dalam rangka menunjang angkutan laut dalam negeri.

20). Sertifikat Perahu Karet (Life Raft Certificate)

Sertifikat Perahu Karet / Life Raft Certificate yaitu sertifikat yang menyatakan bahwa kapal tersebut memiliki alat keselamatan berupa perahu karet.

21) Sertifikat Pemadam Api (Fire Exstinguisher Certificate)

Sertifikat Pemadam Api / Fire Exstinguisher Certificate yaitu sertifikat yang menyatakan bahwa kapal tersebut memiliki peralatan untuk mencegah terjadinya kebakaran.

22) Sertifikat Nasional Sistem Anti Teritip (National Anti Fouling System Certificate)

Sertifikat Nasional Sistem Anti Teritip / National Anti Fouling System Certificate mengacu pada perangkat lapisan, cat, pengobatan permukaan atau digunakan pada kapal untuk mengontrol / mencegah penempelan organisme yang tidak digunakan.

Kemudian pada saat penanganan dokumen keberangkatan kapal pihak syahbandar mengeluarkan surat persetujuan berlayar kapal dimana dibutuhkan lampiran seperti crew list keberangkatan, master sailing, outward manifest dan bukti pelunasan PNBP (Lambu dan Rambu).

\section{b). PT. INALUM}

Berhubung kapal yang disandarkan didermaga TUKS INALUM, agen membuat permohonan untuk menerbitkan surat izin sandar pada PT. INALUM dan menandatangani permohonan izin masuk ke dermaga.

\section{c). BEA dan CUKAI}

Kepentingan atau jasa dalam pengurusan Rencana Kedatangan Sarana Pengangkut ( RKSP ), dan mengawasi barang yang keluar wilayah Indonesia. 


\section{d). PT. PELINDO}

Pelindo bertugas sebagai penyediaan jasa pandu/tunda dan sebagai tempat pengajuan permohonan izin pandu / tunda pada saat proses penyandaran.

\section{e).KANTOR KESEHATAN PELABUHAN}

Merupakan instansi pemerintah yang bertugas untuk memeriksa kesehatan dan penyakit crew kapal serta mengawasi tumbuh-tumbuhan dan hewan yang di bawa keluar masuk pelabuhan oleh kapal.

\section{f).IMIGRASI}

Peran Imigrasi pada kapal asing yang masuk kedalam wilayah Negara Indonesia yaitu dalam mengawasi awak kapal yang datang dan yang akan keluar dari pelabuhan serta serta identitas berupa passport dan buku pelaut.

\section{C.Hambatan-hambatan dalam Prosedur Penanganan Dokumen Kapal di Dermaga TUKS INALUM}

Adapun hambatan yang terkadang terjadi saat prosedur penanganan dokumen kapal yang dihadapi oleh PT. Gesuri Lloyd Cabang Kuala Tanjung antara lain :

1).Terdapat dokumen kapal yang habis masa berlakunya dan perlu diendorse sehingga kapal tidak boleh meninggalkan pelabuhan yang disebabkan owner belum ada kesempatan untuk memperbaharuinya.

2).Keterlambatan pihak owner untuk membayar biaya - biaya operasional

3).Kapal mengalami delay yang disebabkan oleh keterlambatan berangkat dari pelabuhan sebelumnya. Terkadang dermaga penuh dan kapal diinstuksikan untuk berlabuh di area labuh jangkar menunggu kapal yang berada didermaga selesai melakukan aktifitas

4).Cuaca buruk seperti hujan mengakitbatkan aktifitas diberhentikan sementara sampai keadaan memungkinkan untuk melanjutkan kegiatan kapal.

5).Alat yang dipakai untuk melakukan kegiatan bongkar terkadang mengalami kerusakan sehingga menunggu petugas untuk melakukan pemulihan

\section{KESIMPULAN}

Prosedur penanganan dokumen kapal muatan curah kering di dermaga TUKS INALUM oleh perusahaan pelayaran PT. Gesuri Lloyd Cabang Kuala Tanjung masih kurang efektif dan efisien.

\section{DAFTAR PUSTAKA}

Dra Indrayati, Sistem Informasi Akuntasi Edisi 4. Malang : Aditya Media Publishing, 2016

Kamus Besar Bahasa Indonesia Tahun 2016

Komisi Pengawasan Persaingan Usaha Republik Indonesia 2010

Peraturan Menteri No. PM 51 Tahun 2015 Tentang Penyelenggaraan Perhubungan Laut

Undang-undang No. 13 Tahun 1985 Tentang Bea Material Bentuk Undang-undang No.17 Tahun 2008 Tentang Pelayaran 